\title{
Work Engagement and Innovative Work Behavior: Meta-Analysis Study
}

\author{
Devietha Kurnia Sari ${ }^{1, *}$, Ananta Yudiarso ${ }^{2}$, Frikson Christian Sinambela ${ }^{3}$ \\ ${ }^{1}$ Department of Master of Science in Psychology, Faculty of Psychology, UBAYA, Surabaya, Indonesia \\ 2, 3 Faculty of Psychology, UBAYA, Surabaya, Indonesia \\ *Corresponding author.Email:s154219002@student.ubava.ac.id
}

\begin{abstract}
Work Engagement is referred to as the motivation employees have in involving and being enthusiastic about their work. An engaged employee will positively involve and strive to contribute to the organization through higher productivity, efficiency, and vast innovation. A motivational condition such as Work Engagement stimulates employee's positive thought-action, which then elevates their Innovative Work Behavior. Many previous studies examined the relationship between Work Engagement and Innovative Work Behavior with inconsistent results. This study aims to evaluate several research results quantitatively through a meta-analysis test related to the magnitude of the correlation between Work Engagement and Innovative Work Behavior. This study involved 26 journals with 26 correlation coefficients. The statistical test shows that Work Engagement and Innovative Work Behavior have a medium effect size correlation $(r=0.46$ with $95 \% \mathrm{CI}$ between $0.423-0.506)$. The heterogeneity of $\mathrm{I} 2=90.2 \%$, thus using a random-effect model. There was no publication bias (Egger bias, $\mathrm{p}=0.23$ ). Work Engagement has a medium to large correlation effect size with Innovative Work Behavior. The research results indicate that Work Engagement is not a dominant factor; other factors form Innovative Work Behavior.
\end{abstract}

Keywords: Innovative Work Behavior, Work Engagement, Meta-analysis

\section{INTRODUCTION}

Several studies suggest that Innovative Work Behavior has a relationship with Work Engagement. Innovative Work Behavior is a process carried out by employees starting from recognizing problems, generating new ideas and solutions, promoting and building support for these ideas, to producing prototypes or models to realize ideas for organizational benefits [1]. Innovative Work Behavior is associated with challenging and complex tasks that include a variety of employee cognitive and social activities [2].

Innovative Work Behavior is a key factor that contributes to innovation and organizational effectiveness, especially in the current Industry 4.0 era [3] [4]. Innovative Work Behavior includes idea generation, efforts to promote ideas (idea promotion), and implementing new ideas (idea realization). Activities carried out by employees as a form of Innovative Work Behavior, namely; generate, promote, discuss, modify, and implement creative ideas [3] [5]. Employees who are sensitive to change, continuously develop knowledge, can generate new solutions and ideas, and are willing to improve their work will provide benefits to organizational innovation [6].

Innovations made by employees in organizations can increase the competitiveness of knowledge-based organizations [1]. Employees with high skills in ideagenerating will be more appreciated. Employees who are only able to do routine tasks and cannot create ideas or innovate will be at risk of losing their jobs.

Innovative Work Behavior depends on the engagement or totality of employees in the workplace [3]. Work engagement or what is called Work Engagement has a positive effect on Innovative Work Behavior. Work Engagement defined as engagement and enthusiasm for work [7].

The dimensions of Work Engagement divided into three dimensions, namely vigour, dedication, and absorption [8]. Vigour involves a high level of energy 
and mental endurance at work. Dedication refers to being intensely engaged in work and experiencing a sense of significance, enthusiasm, inspiration, pride and challenges towards work. Absorption refers to employees who feel happy, enjoy their work, and are immersed in work which leads to time passes fast while doing work.

Employees who are positively engaged will use their efforts to contribute to the organization by performing higher productivity, greater efficiency and innovation, and more meaningful customer impact. Based on the Broaden-and-Build Theory put forward by Fredrickson, employees who experience positive emotions will stimulate positive thoughts, thereby increasing the chances of innovative work behavior [3].

Several studies have revealed the relationship between Work Engagement and Innovative Work Behavior. Agarwal (2014) states that Work Engagement has a positive influence on Innovative Work Behavior [9]. Jung \& Yoon (2018) stated that Work Engagement could positively influence Innovative Behavior [10].

Aspects of Work Engagement are closely related to aspects of Innovative Work Behavior. Innovative Work Behavior involves the creation of something new (idea generation), which requires employees to concentrate and enjoy their work. Thus, it can be said that it is related to the absorption variable in Work Engagement. Furthermore, when an employee needs to convince other employees about new ideas and changes that will be implemented (idea promotion), the employee needs to have the mental strength to be consistent with his efforts. This is related to the vigour variable. Innovative work behavior also involves cognitive and emotional roles. To continuously invest cognitive and emotional potential in idea implementation, an employee will experience a sense of significance, pride, and challenges with the activities carried out, as well as having a passion for their work [3]. This is related to the dedication variable.

Some researchers referring to several literacy sources argue the relationship between Work Engagement and Innovative Work Behavior. However, systematic research related to the exploration of the effect-size correlation of the relationship between Work Engagement and Innovative Work Behavior is still inadequate, especially for the most recent literature sources. This study was conducted to quantitatively evaluate some of the results of previous studies that examined the relationship between Work Engagement and Innovative Work Behavior with inconsistent results. Meta-analysis statistical test was used in this study to improve the effect size analysis of the correlation between Work Engagement and Innovative Work Behavior.

\section{METHOD}

\subsection{Literature Study}

A literature study was conducted to collect data that met the research requirements. The study was conducted using three journal data sources, "Google Scholar", "Science-Direct", and "Emerald Insight". Researchers examined research journals that involved work engagement and innovative work engagement. The keywords used are "Innovative work Behavior", "Innovative Behavior", "Innovativeness", "Innovation at Work", "Work Engagement", "Employee Engagement", and "Engagement". Keywords are used independently or in combination to maximize the range of literature searches.

The research journals' screening is carried out in the following steps: (1) evaluating the research title, the literature contains two research variables, (2) examining the research abstract. Literature with appropriate abstracts was collected for further screening according to inclusion and exclusion criteria.

\subsection{Inclusion and Exclusion}

The literature obtained was then selected based on inclusion criteria. Studies that meet the requirements are studies that (1) have gone through a peer-reviewed process, (2) published during 2009-2019, (3) written in English, (4) there is a correlation coefficient (r) between each dimension, Work Engagement and Innovative Work Engagement, (5) there is information on the number of samples (n) and the characteristics of the participants. Incomplete data will be excluded from data analysis, (6) using measuring instruments that are the same or similar to each other.

\subsection{Data Processing}

The data were processed using the meta-analysis method. Meta-analysis is a statistical method to combine the results of independent empirical research studies [11]. The current meta-analysis using the Hedges-Olkin method resulted in combined correlation values, inconsistency $\left(\mathrm{I}^{2}\right)$, and publication bias. The literature obtained is summarized based on specific information provided such as author's name (including the year of publication), country, the number of samples, the average age of the sample, the scale of Work Engagement used, the scale of Innovative Work Behavior used, and correlation 
coefficient (r) of Work Engagement and Innovative Work Behavior. All information is summarized in table 1 .

Data was processed using the statistical software Stats-Direct 3.0 free trial version. The data entered are the author's name and year of publication, the correlation coefficient ( $r$ ) between Work Engagement and Innovative Work Behavior, and the number of samples involved. A random-effect model was used with a $95 \% \mathrm{CI}$, given that not every study has the same effect size. The effect size correlation can be seen from the Hedges-Olkin random correlation. The combined correlation is considered small if $<0.3$, medium if 0.3 $<\mathrm{r}<0.49$ and high if $\mathrm{r}>0.5$.

Study heterogeneity was evaluated from the Cochran Q coefficient, calculated as a weighted sum of the squared differences between individual study effects and the combined effect across studies. Publication bias occurs when publication depends not only on the study's quality but also on the hypothesis tested, the significance and direction of the effects detected. Egger's bias value was used to test for publication bias.

\section{RESULT}

At the end of the study literature, 71 studies were found. Thirty-one studies were omitted due to irrelevant abstracts, resulting in 40 remaining studies for further selection. Six literature was omitted because the full-text version was inaccessible. Five studies do not show the correlation value for the correlation between Work Engagement and Innovative Work Engagement variables. Two studies use different items on the statistical measurement of the Innovative Work Behavior variable. One study was omitted because there was a duplication of sample data. In the end, 26 studies were deemed eligible. The study selection process is illustrated in Figure 1 below.
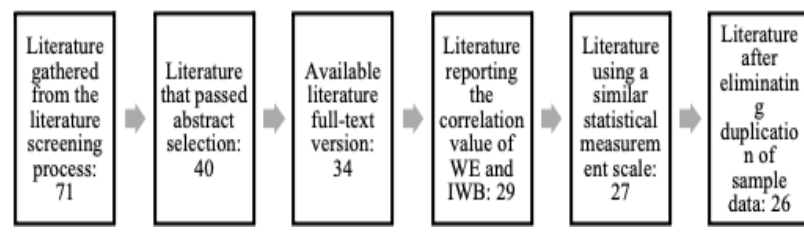

Figure 1 Journal Selection Flow for Meta-Analysis Studies

The current study involved 26 studies with a total of 12801 participants. The literature obtained came from various countries in Asia and Europe and was published between 2011-2019. The sample size also varies from 168 to 3098. The Work Engagement statistical measure used is the UWES [12], Salanova et al.'s [13], Lee et al.'s [14], Soane et al.'s [15], Tsai's [16], and Rich et al.'s [17], while the Innovative Work Behavior statistical measures used are Janssen's [5], Van Yperen et al.'s [18], Scott \& Bruce's [19], Spiegelaere et al.'s [20], Gupta, Singh's, \& Bhattacharya's [21], Jung \& Yoon's [10], Tsai's [16], and $\mathrm{Ng}$ and Lucianetti's [23]. The correlation coefficient (r) of each study is described in Table 1. 
Table 1. Summary of Literature Data

\begin{tabular}{|c|c|c|c|c|c|c|c|}
\hline Authors & Country & $\mathbf{N}$ & $\begin{array}{c}\text { Mean } \\
\text { Age }\end{array}$ & Job & IWB Scale & WE Scale & $\mathrm{r}$ \\
\hline$[31]$ & Netherlands & 262 & $\mathrm{~N}$ & Self-employed & Janssen's & UWES & 0.40 \\
\hline [32] & Ireland & 168 & 29 & $\begin{array}{l}\text { (cross-sectional } \\
\text { survey) }\end{array}$ & Janssen's & UWES & 0.46 \\
\hline [3] & India & 979 & 30.4 & $\begin{array}{l}\text { Managers in } \\
\text { service sector }\end{array}$ & Janssen's & UWES & 0.38 \\
\hline [33] & China & 193 & NA & $\begin{array}{l}\text { Supervisors in } \\
\text { telecommunication } \\
\text { company }\end{array}$ & $\begin{array}{l}\text { Scott \& } \\
\text { Bruce's }\end{array}$ & $\begin{array}{l}\text { Salanova } \\
\text { et al's }\end{array}$ & 0.47 \\
\hline [15] & $\begin{array}{l}\text { United } \\
\text { Kingdom }\end{array}$ & 872 & 41.4 & $\begin{array}{l}\text { Recycling and } \\
\text { waste management } \\
\text { company }\end{array}$ & $\begin{array}{l}\text { Janssen \& } \\
\text { Van Yperen's }\end{array}$ & $\begin{array}{l}\text { Soane, } \\
\text { Truss, } \\
\text { Alfes, } \\
\text { Shantz, } \\
\text { Rees, \& } \\
\text { Gatenby's }\end{array}$ & 0.39 \\
\hline [26] & Taiwan & 267 & NA & $\begin{array}{l}\mathrm{R} \& \mathrm{D} \text { engineers \& } \\
\text { supervisors }\end{array}$ & Janssen's & UWES & 0.64 \\
\hline$[34]$ & Ireland & 192 & 29 & $\begin{array}{l}\text { (cross-sectional } \\
\text { survey) }\end{array}$ & Janssen's & UWES & 0.44 \\
\hline [9] & India & 323 & 35.7 & $\begin{array}{l}\text { Manufacturing \& } \\
\text { pharmaceutical } \\
\text { companies }\end{array}$ & Janssen's & UWES & 0.34 \\
\hline$[35]$ & Spain & 180 & 42.1 & Entrepreneurs & Janssen's & UWES & 0.56 \\
\hline$[36]$ & South Korea & 296 & NA & Various industries & $\begin{array}{l}\text { Scott \& } \\
\text { Bruce's }\end{array}$ & UWES & 0.65 \\
\hline$[20]$ & Belgium & 3098 & 39 & Various industries & $\begin{array}{l}\text { Spiegelaere et } \\
\text { al's }\end{array}$ & $\begin{array}{l}\text { Salanova } \\
\text { et al's }\end{array}$ & 0.41 \\
\hline$[37]$ & India & 393 & 36.6 & Managers & Janssen's & UWES & 0.44 \\
\hline$[38]$ & Israel & 419 & 39.4 & $\begin{array}{l}\text { Public sector } \\
\text { organizations }\end{array}$ & $\begin{array}{l}\text { Scott \& } \\
\text { Bruce's }\end{array}$ & UWERS & 0.49 \\
\hline [39] & India & 294 & NA & $\begin{array}{l}\text { Public sector } \\
\text { banks }\end{array}$ & $\mathrm{Hu}$ et al's & UWES & 0.51 \\
\hline$[21]$ & India & 467 & 42.1 & $\begin{array}{l}\text { (cross-sectional } \\
\text { study) }\end{array}$ & $\begin{array}{l}\text { Gupta, Singh, } \\
\& \\
\text { Bhattacharya's }\end{array}$ & UWES & 0.57 \\
\hline$[40]$ & Pakistan & 376 & NA & $\begin{array}{l}\text { R\&D and IT } \\
\text { sector }\end{array}$ & $\begin{array}{l}\text { Scott \& } \\
\text { Bruce's }\end{array}$ & UWES & 0.23 \\
\hline
\end{tabular}




\begin{tabular}{|c|c|c|c|l|l|l|l|}
\hline$[41]$ & South Korea & 290 & NA & Hotels & Janssen's & Lee et al's & 0.58 \\
\hline$[24]$ & South Korea & 400 & NA & various industries & Janssen's & UWES & 0.69 \\
\hline$[10]$ & South Korea & 383 & NA & $\begin{array}{l}\text { Deluxe (five-star) } \\
\text { hotels }\end{array}$ & $\begin{array}{l}\text { Jung \& } \\
\text { Yoon's }\end{array}$ & UWES & 0.39 \\
\hline$[16]$ & $\begin{array}{c}\text { USA, UK, } \\
\text { India }\end{array}$ & 608 & NA & $\begin{array}{l}\text { Knowledge } \\
\text { workers }\end{array}$ & Tsai's & Tsai's & 0.56 \\
\hline$[42]$ & India & 603 & 29.5 & IT & Janssen's & UWES & 0.57 \\
\hline$[43]$ & China & 281 & NA & $\begin{array}{l}\text { Pharmaceutical, } \\
\text { electronics, and } \\
\text { automobile } \\
\text { manufacturing }\end{array}$ & $\begin{array}{l}\text { Scott \& } \\
\text { Bruce's }\end{array}$ & UWES & 0.43 \\
\hline$[44]$ & India & 585 & NA & $\begin{array}{l}\text { Luxury (four and } \\
\text { five star) hotels }\end{array}$ & Janssen's & $\begin{array}{l}\text { Lepine, \& } \\
\text { Crawford's }\end{array}$ & 0.26 \\
\hline$[45]$ & China & 263 & NA & Marketing & $\begin{array}{l}\text { Scott \& } \\
\text { Bruce's }\end{array}$ & UWES & 0.25 \\
\hline$[46]$ & China & 377 & NA & Nurses & $\begin{array}{l}\text { Ng and } \\
\text { Lucianetti's }\end{array}$ & UWES & 0.50 \\
\hline$[47]$ & Netherlands & 232 & NA & IT Company & Janssen's & UWES & 0.30 \\
\hline
\end{tabular}

\subsection{Discussion}

The results of the meta-analysis are consistent with the results of research which have so far been understood that there is a positive correlation between Work Engagement and Innovative Work Behavior. The result of the effect size, which is medium to large $(\mathrm{r}=0.46)$ shows that there is a moderate relationship between Work Engagement and Innovative Work Behavior.

These findings illustrate that Work Engagement is not yet a strong single predictor of Innovative Work Behavior. Work Engagement can serve as a mediator based on the Job Demands-Resources (JD-R) Model and other research. In other words, other factors can lead to Work Engagement and further demonstrate Innovative Work Behavior.

Based on the JD-R Model, Innovative Work Behavior is explained as positive outcomes. The JD-R model assumes that job resources and personal resources can produce Innovative Work Behavior mediated by Work Engagement [24]. Previous researchers examined that Leader-Member Exchange as job resources has a positive relationship to
Innovative Work Behavior through Work Engagement [3].

Previous study explains that there is a mediating effect of Work Engagement [25]. Employees who show work engagement have a strong indirect influence on the relationship between Organizational Procedural Justice and Knowledge Sharing and Innovative Work Behavior. Work Engagement, together with other factors, namely Coping Capacity, can influence Innovative Work Behavior [26]. Employees who have high engagement will be more likely to behave innovatively by activating the Coping Strategy to face work challenges. Work Engagement fully mediates the relationship between Psychological Contracts and Innovative Work Behavior [27].

competence, relatedness, and meaning. By meeting these basic needs, employees will be stimulated to generate new ideas [30]. Furthermore, meeting the emotional needs of employees can encourage initiatives to empower within the organization so that it can ultimately strengthen innovative behavior [31]. 


\subsection{Conclusion}

The results of the statistical test show that Work Engagement and Innovative Work Behavior have a moderate effect size correlation. These results suggest that Work Engagement and Innovative Work Behavior have a significant but weak relationship. Work Engagement is not the dominant factor in the relationship with Innovative Work Behavior; other factors lead to the innovative behavior of employees at work.

In future studies, a research model should be used to examine the relationship between Work Engagement and Innovative Work Behavior. The relationship between the Work Engagement and Innovative Work Behavior can use the Job DemandsResources (JD-R) model. The JD-R model assumes that job resources, personal resources, and job demands can produce Innovative Work Behavior mediated by Work Engagement.

This study has a limited small sample size, so it is necessary to be careful in generalization efforts. Heterogeneity arises due to the use of a measurement scale for each different variable and different participant backgrounds, thus affecting the results of the meta-analysis.

\section{AUTHORS' CONTRIBUTIONS}

DKS created the idea for the topic of the study, drafted, and edited the manuscript. AY created the idea for the method of the study. All authors interpreted the results and analysed the data, compiled the data and tables in the manuscript. AY \& FCS oversaw the study as the professional and guided the writing of the manuscript. All authors have read and approved of the manuscript.

\section{ACKNOWLEDGMENTS}

The study was supported by the 2020 Faculty of Psychology, University of Surabaya.

\section{REFERENCES}

[1] A. Carmeli, R. Meitar, J. Weisberg. Selfleadership Skills and Innovative Behavior at Work. Int. J. Manpow. 27(1) (2006) 75-90. doi: $10.1108 / 01437720610652853$

[2] N. Doerner. Innovative Work Behavior: The Roles of Employee Expectations and Effects on Job Performance. 2012. Available from: https://www.semanticscholar.org/paper/Innovati ve-Work-Behavior\%3A-The-Roles-of-
Employee-and-

Doerner/5eff4a778523c6f0c7b6166280afc57578 da2fb5

[3] U. Agarwal U, S. Datta, S. Blake-Beard, S. Bhargava. Linking LMX, Innovative Work Behavior and Turnover Intentions: The mediating role of work engagement. Career Dev Int. 17(3) (2012) 208-230 doi: $10.1108 / 13620431211241063$

[4] Duradoni M, Fabio A. Intrapreneurial SelfCapital and Sustainable Innovative Behavior within Organizations. Sustainability. 11(2) (2019) 322.

[5] Janssen O. How Fairness Perceptions Make Innovative Behavior More or Less Stressful. J. Organ. Behav. 25(2) (2004) 201-216. doi: 10.1002/job. 238

[6] Hoyrup S. Employee-driven innovation: A new phenomenon, concept and mode of innovation. London: Palgrave Macmillan; c2012.

[7] Lopez S. The Encyclopedia of Positive Psychology. Chichester: Blackwell Publishing; c2009.

[8] Schaufeli W, Bakker A, Salanova M. The Measurement of work Engagement with a Short Questionnaire: A cross-national study. Educ Psychol Meas. 66(4) (2006) 701-716. doi: $10.1177 / 0013164405282471$

[9] Agarwal U. Examining the Impact of Social Exchange Relationships on Innovative Work Behavior: Role of work engagement. Team Perform. Manag. 20(3-4) (2014) 102-120. doi: 10.1108/TPM-01-2013-0004

[10] Jung H, Yoon H. Improving Frontline Service Employees' Innovative Behavior Using Conflict Management in the Hospitality Industry: The mediating role of engagement. Tour. Manag. 69 (2018) 498-507. Available from: Doi:10.1016/j.tourman.2018.06.035

[11] Hedges L. Meta-Analysis. J Educ Behav Stat. 17 (1992) 279-296. Doi: $10.3102 / 10769986017004279$

[12] Schaufeli W, Taris T, Bakker A. Dr Jekyll or Mr Hyde: on the differences between work engagement and workaholism in Burke, R.J. Research Companion to Working Time and Work Addictio., Northampton: Edward Elgar; c2006. 
[13] Salanova M, Agut S, Peiro J. Linking Organizational Resources and Work Engagement to Employee Performance and Customer Loyalty: The mediation of service climate. J Appl Psychol. 90 (2005) 1217-1227

[14] Lee Y, Kim S, Kim S. The Impact of Internal Branding on Employee Engagement and Outcome Variables in The Hotel Industry. Asia Pac. J. Tour. Res. 19(12) (2014) 1359-1380

[15] Alfes K, Truss C, Soane E, Rees C, Gatenby M. The Relationship Between Line Manager Behavior, Perceived HRM Practices, and Individual Performance: Examining the Mediating Role of Engagement. Hum. Resour. Manag. J. 52(6) (2013) 839-859. doi:10.1002/hrm.21512

[16] Tsai S. Innovative Behavior of Knowledge Workers and Social Exchange Attributes of Financial Incentive: Implications for knowledge management. J. Knowl. Manag. 2018. Doi:10.1108/jkm-07-2017-0293

[17] Rich B, Lepine J, Crawford E. Job Engagement: Antecedents and effects on job performance. Acad Manage J. 53(3) (2010) 617-635.

[18] Van Yperen, N, Janssen O. Employees' Goal Orientations, The Quality of Leader-Member Exchange, and The Outcomes of Job Performance and Job Satisfaction. Acad Manage J. 47 (2004) 368-384.

[19] Scott S, Bruce R. Determinants of Innovative Behavior: A path model of individual innovation in the workplace. Acad Manage J. 37 (1994) 580607.

[20] Spiegelaere S, Gyes G, Witte H, Hootegem G. Job Design, Work Engagement and Innovative Work Behavior: A multi-level study on Karasek's learning hypothesis. Manag. Rev. 26(2) (2015) 123-137.Doi:10.1688/mrev-2015-02-

DeSpiegelaere.

[21] Gupta V, Singh S, Bhattacharya A. The Relationships between Leadership, Work Engagement and Employee Innovative Performance: Empirical Evidence from the Indian R\&D Context. Int. J. Innov. Manag. 21(07) (2017) Doi:10.1142/s1363919617500554

[22] Ng T, Lucianetti L. Within-Individual Increases in Innovative Behavior and Creative, Persuasion, and Change Self-Efficacy Over Time: A social- cognitive theory perspective. J Appl Psychol. 101 (2016)14-34. Doi: 10.1037/ap10000029

[23] Demerouti E, Bakker A. The Job DemandsResources Model: Challenges for future research. SA J. Ind. Psychol. 37(2) (2011) 1-9.

[24] Kim W, Park J. Examining Structural Relationships between Work Engagement, Organizational Procedural Justice, Knowledge Sharing, and Innovative Work Behavior for Sustainable Organizations. Sustainability. 2017;9(2):205. Doi:10.3390/su9020205

[25] Kwon K, Kim T. An Integrative Literature Review of Employee Engagement and Innovative Behavior: Revisiting the JD-R model. Hum. Resour. Manag. Rev. $30 \quad$ (2019) Doi:10.1016/j.hrmr.2019.100704

[26] Chang H, Hsu H, Liou, J, Tsai C. Psychological Contracts and Innovative Behavior: A moderated path analysis of work engagement and job resources. J. Appl. Soc. Psychol.. 43(10) (2013) 2120-2135. Doi: 10.1111/jasp. 12165

[27] Ratnaningsih I, Prasetyo A, Prihatsanti U. Predicting Innovative Behavior Among Employees in a Manufacturing Company: The Role of Psychological Capital. Anima Indonesian Psychol J. 31 (2016) 84-90.

[28] Montani F, Odoardi C, Battistelli A. Individual and Contextual Determinants of Innovative Work Behavior: Proactive goal generation matters. J. Occup. Organ. Psychol.. 87(4) (2014) 645-670. Doi:10.1111/joop.12066

[29] Deci E, Ryan R. Self-Determination Theory and the Facilitation of Intrinsic Motivation, Social Development, and Well-Being. Am Psychol. 55(1) (2000) 68-78.

[30] Paul A, Bhattacharyya D, Anand S. Green Initiatives for Business Sustainability and Value Creation. Pennsylvania: IGI Global; c2017.

[31] Gorgievski M, Bakker A, Schaufeli W. Work Engagement and Workaholism: Comparing the Self-Employed and Salaried Employees. J Posit Psychol. 5(1) (2010) 83-96. Doi:10.1080/17439760903509606

[32] Chughtai A, Buckley F. Work Engagement: Antecedents, the Mediating Role of Learning Goal Orientation and Job Performance. Career Dev Int. 16(7) (2011) 684-705. Doi:10.1108/13620431111187290 
[33] Aryee S, Walumbwa F, Zhou Q, Hartnell C. Transformational Leadership, Innovative Behavior, and Task Performance: Test of Mediation and Moderation Processes. Hum. Perform. 25(1) (2012) 1-25. Doi:10.1080/08959285.2011.631648.

[34] Chughtai A. Linking Affective Commitment to Supervisor to Work Outcomes. J. Manag. Psychol. 28(6) (2013) 606-627. Doi:10.1108/jmp-09-2011-0050

[35] Gorgievski M, Juan A, Bakker B. Relating Work Engagement and Workaholism to Entrepreneurial Performance. J. Manag. Psychol. 29(2) (2014) 106-121. Doi:10.1108/jmp-062012-0169.

[36] Park Y, Song J, Yoon S, Kim J. Learning Organization and Innovative Behavior. Eur. J. Train. Dev. 38(1) (2014) 75-94. Doi:10.1108/ejtd-04-2013-0040.

[37] Agarwal U. Examining Perceived Organizational Politics among Indian Managers: Engagement as Mediator and Locus of Control as Moderator. Int. J. Organ. Anal. 24(3) (2016) 415-437. Doi: 10.1108/IJOA-07-2014-0786

[38] Eldor L. The relationship between perceptions of learning climate and employee innovative behavior and proficiency. Pers. Rev. 46(8) (2017) 1454-1474. Doi:10.1108/pr-08-2016-0202

[39] Garg S, Dhar R. Employee service innovative behavior. Int. J. Manpow. 38(2) (2017) 242-258. Doi:10.1108/ijm-04-2015-0060

[40] Khan M, Malik M. My Leader's Group is My Group: Leader-Member Exchange and Employees' Behaviors. Eur. Bus. Rev. 29(5) (2017) 551-571. Doi:10.1108/ebr-01-2016-0013

[41] Kim M, Koo D. Linking LMX, Engagement, Innovative Behavior, and Job Performance in Hotel Employees. Int. J. Contemp. Hosp. Manag. 29(12) (2017) 3044-3062. Doi: 10.1108/IJCHM06-2016-0319

[42] Jason V, Geetha S. Regulatory focus and innovative work behavior: The role of work engagement. Curr Psychol. 2019. Doi:10.1007/s12144-019-00220-1

[43] Li H, Sajjad N, Wang Q, Ali A, Khaqan Z, Amina S. Influence of Transformational Leadership on Employees' Innovative Work Behavior in Sustainable Organizations: Test of Mediation and
Moderation Processes. Sustainability. 11(6) (2019) 1594. Doi:10.3390/su11061594

[44] Nazir O, Islam J. Influence of CSR-Specific Activities on Work Engagement and Employees' Innovative Work Behavior: An Empirical Investigation. Curr. Issues Tour. (2019) 1-19. Doi:10.1080/13683500.2019.1678573

[45] $\mathrm{Wu} \mathrm{T}, \mathrm{Wu} \mathrm{Y}$. Innovative Work Behaviors, Employee Engagement, and Surface Acting: A Delineation of Supervisor-Employee Emotional Contagion Effects. Manag. Decis. 57(11) (2019) 3200-3216. Doi: 10.1108/MD-02-2018-0196

[46] Yang K, Zhou L, Wang Z, Lin C, Luo Z. Humble Leadership and Innovative Behavior Among Chinese Nurses: The Mediating Role of Work Engagement. J. Nurs. Manag. 2019. Doi:10.1111/jonm.12879

[47] Zyl L, Oort A, Rispens S, Olckers C. Work Engagement and Task Performance Within a Global Dutch ICT-consulting firm: The Mediating Role of Innovative Work Behaviors. Curr Psychol. 2019. Doi:10.1007/s12144-01900339-1 